\title{
Проблемы современной пушкинистики: по следам Болдинских чтений (2011-2016 гг.)
}

\author{
Марина Уртминцева (Нижний Новгород)
}

Научная конференция Болдинские чтения, ежегодно проходящая в селе Большое Болдино Нижегородской области, - один из наиболее известных научных форумов, получивших мировую известность. В разные годы в конференции принимали участие ученые-пушкинисты из Америки, Австралии, Германии, Чехии, Венгрии, Болгарии, Польши, Хорватии, Сербии, Японии, Китая.

Инициатива проведения Болдинских итений, а также идея создания мемориального музея А. С. Пушкина в селе Большое Болдино, который был открыт в 1969 году, принадлежала профессору Горьковского университета, доктору филологических наук Г. В. Краснову. В течение многих лет он был бессменным научным руководителем чтений, вдохновителем и учителем молодых ученых Советского Союза, а затем России. Его перу принадлежат многочисленные статьи, посвященные различным аспектам творчества Пушкина, он автор статей в «Онегинской энииклопедии», автор монографии «Пушкин. Болдинские страницы» (1984), редактор-составитель коллективной монографии «Под знаком Пушкина. Болдино» (2003). Под его руководством и при его содействии в с. Б. Болдино с 1974 года начала работу ежегодная научная конференция Болдинские чтения, была создана научная школа пушкинистики, которую прошли такие известные ученые, как В. А. Грехнев («Лирика Пушкина», «Болдинская лирика Пушкина») и Н. М. Фортунатов («Эффект Болдинской осени», «Бодинские диалоги»). В течение многих лет активными участниками Болдинский чтений были чешские специалисты-филологи, среди которых профессор Иво Поспишил - директор Института славистики Масарикова университета в г. Брно, Кветуше Лепилова (Масариков университет), Йосеф Догнал (Масариков университет), Зденек Пехал (Университет им. Палацкого в г. Оломоуц), доклады и статьи которых неизменно вызывали интерес научной общественности России.

Доклады и опубликованные в сборниках Болдинских итений статьи дают представление о направлениях исследований современных ученых, посвященных творчеству А. С. Пушкина. Среди них материалы, посвященные изучению творческих параллелей, раскрывающих глубинные связи произведений поэта с художественным творчеством русских писателей XVIII-XXI веков. Такой подход к исследованию характеризует доклады С. Пяткина «Пушкинианство» Сергея Есенина: «осенний сюжет», О. Федотова «Две Мадонны» (в сонетах Мичкевича и Пушкина), Е. Прощина «Стихотворение А. С. Пушкина « $K$ ***» («Я помню чудное мгновенве...») в речепиии поэтов лианозовской школь», «А. С. Пушкин - сокровенный герой прозы М. Павича» (Т. Попович, Сербия), «Понимание А. Бельм пушкинской поэмы «Медный всадник» (Н. Какинума, Япония), Г. Гуменной «Пушкинская традииия в шутливой поэме Б. А. Садовского (поэма «Она»), М. Уртминцевой «Аксиология пушкинского текста в проекте "Новый русский роман», И. Сергеев «Отиы и дети» и др. Основным методом исследования в названных докладах является феноменологический подход к изучению различных аспектов восприятия и переработки впечатлений, формирующих идейно-художественную структуру послепушкинской прозы и поэзии, что оказывается основанием для корректировки существующих представлений об эволюции литературного процесса, движения его от «начальной» точки - творчества Пушкина к литературной ситуации исследуемого периода. 
Историко-функциональный метод исследования определяет характер работ, выполненных в жанре «диалога», результат которых связан с решением вопроса о своеобразии переосмысления различных элементов художественного мира пушкинского текста: его мотивной структуры, аллюзий и реминисценций, эпиграфов. Это доклады и статьи В. Кошелева «Пушкин: поэтика «исходного мотива», посвященная анализу его функций, 3. Сазоновой «Месть или возмездие: сплетение мотивов в «Маленьких трагедиях» А. С. Пушки на», «Мотивы демонизма в произведениях Пушкина, Лермонтова, Гончарова» (А. Молнар, Венгрия), роли пушкинских аллюзий в докладе И. Юхновой «Об одной пушкинской аллюзии в «Войне и мире»: два тулупчика» и реминисценций в современной поэзии, анализ которых был дан в докладе Е. Прощина «Функиия пушкинской иитаты в поэзии неомодерна и неоавангарда», смысловой потенциал эпиграфа как паретекста, рассмотренный в докладе Г. Гуменной «Пушкинские эпиграфы в сборнике Б. Садовского «Позднее утро».

Исследовательский потенциал личности характеризует работы, целью которых становится выявление скрытых смыслов, казалось бы, хорошо знакомого читателям текста. Доклады такого плана позволили на основании научно обоснованного анализа дать оригинальную интерпретацию произведения Пушкина, обнаружить его смысловой потенциал, показать «жизнь» текста в нашем времени. Этой проблеме были посвящены доклады и статьи В. Листова «Поэт о «Смут ном времени» (А. С. Пушкин о возможном продолжении трагедии «Борис Годунов»), «Изложение символики и общения героев в "Кавказском пленнике» Пушкина на фоне постколониальной кри тики» (М. Фрайзе, Германия), «Сказка о мертвой иаревне и семи богатырях» А. С. Пушкина в контексте неофичиальной истории и мифов петербургского иикла» (Д. Крыстева, Болгария).

По-прежнему актуальным для пушкинистов оказывается так называемый «герметичный» анализ пушкинских произведений, целью которого является исследование поэ- тики отдельного произведения, как правило, «выведенного» из историко-литературного и биографического контекста. При всей, казалось бы, ограниченности такого подхода, он оказывается плодотворным в тех случаях, когда ученый ставит перед собой задачу воссоздания художественных законов отдельного текста. В качестве примера можно сослаться на статьи В. Листова «К истолкованию образа Лизаветы Ивановны из «Пиковой дамъ», «Знак в лирике Пушкина на примере стихотворения «Что в имени тебе моем?» (М. Леонова, Германия), Н. Вершининой «Поэтика временных соответствий в романе А. С. Пушкина «Евгений Онегин», «Персонаж второго плана как орудие Провидения («Капитанская дочка» A. C. Пушкина) (О. Глувко, Польша), «Антиномии в «Медном всаднике» Й. Догнала (Чехия).

Значительный пласт пушкинских штудий составили доклады, посвященные изучению творчества поэта в контексте других видов искусства, где рассматриваются контактные и дистантные связи литературного текста и произведения музыки, живописи, графики, театрального и киноискусства. Примечательно, что всем искусствоведческим докладам свойственен синтетический характер, в них предпринимались попытки «прочитать» и истолковать пушкинские произведения с использованием методического инструментария, принятого в исследованиях других видов искусства. Это доклады Н. Ростовой «O творческом наследии А. С. Пушкина в истории отечественного кино», И. Ушакова «Эхо поэта»: вокальный иикл Бенджамина Бриттена на слова Пушкина», М. Уртминцевой «Пушкин в творчестве художника книги Н. В. Ильина», С. Акимова «Об особенностях экфрасиса у A. C. Пушкина», Н. Тепловой (Канада) «Таинственные баррикады»: адаптачия «Евгения Онегина» Мишеля Понта для франиузского драматического театра».

В последнее время значительно активизировались исследования в области анализа переводов Пушкина на языки мира. На Болдинских чтениях не только звучат стихи поэта на болгарском, чешском, хорватском, шведском, 
итальянском языках, но и ставятся проблемы переводческой рецепции и интерпретации образной системы пушкинских поэтических и прозаических текстов, проводится анализ речевых и языковых соответствий оригиналу и обозначаются причины их нарушений. Этим вопросам были посвящены доклады Р. Божич (Хорватия) «Стихотворение «Поэту» в двух переводах на хорватский язык», Ван Лие (Китай) «Особенности переводов произведений А. С. Пушкина и основные направления изучения его наследия в Китае», К. Олоффсон (Швеция) «Метель» $A$. С. Пушкина в шведских переводах», Н. Е. Теплова (Канада) «Евгений Онегин» Жака Ширака или переводы-призраки и их роль в рецепчии переводной литературь», И. Рудзевич (Польша) «Пушкин в Польше (2000-2010)».

Еще один аспект исследований современной пушкинистики связан с изучением истории пушкиноведения. Этой проблеме были посвящены доклады, основанные на анализе эффективности различных подходов к изучению творчества поэта в истории отечественного и зарубежного литературоведения, критики и публицистики. Названная проблематика рассматривается в докладах А. Труханенко (Украина) «Имя Пушкина по львовских ROZMAITOSCI (1827)», Е. Сартакова «Твориество Пушкина в критике журнала C. A. Бурачка «Маяк», Т. Попович (Сербия) «Пушкин и русские формалисть», М. Уртминцевой «Пушкин в каприйских лекциях М. Горького», Ю. Изумрудова «Борис Садовской и его статья «Наполеон в русской поэзии».

Завершая краткий обзор научных исследований в области пушкинистики, скажем, что в 2009 году по инициативе директора музея в Большом Болдино Ю. Жулина стартовал проект издания серии «Монографии участников Болдинских чтений», в которую вошли книги В. Кошелева «Онегина воздушная громада», В. Листова «Судъба коренного поэта», Н. Вершининой и О. Глувко «Пушкин в движении культуры: проблемы поэтики и твориеские параллели», И. Альми «Пушкин в контексте русской поэзии и прозы», Н. Михайловой «Болдинская осенъ», Б. Кондратьева и Н. Суздальцевой «Пушкин и Достоевский: миф, сон, традииия», С. Пяткина «Пушкин в худождественном сознании Есенина».

Хочется надеяться, что творческие, научные и учебные контакты чешских и русских исследователей А. С. Пушкина будут продолжены и будут содействовать укреплению культурных связей ученых России и Чехии.

\section{Marina Urtminceva \\ Lobachevsky University \\ Nizhny Novgorod \\ urtminzeva@yandex.ru}

